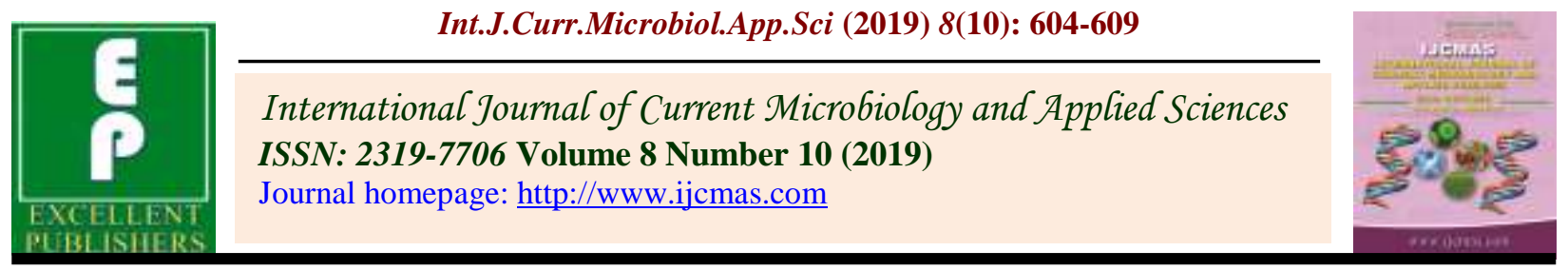

Original Research Article

https://doi.org/10.20546/ijcmas.2019.810.068

\title{
Effect of Co-inoculation of different Bacterial Cultures with Rhizobium phaseoli on Soil Biological Properties
}

\author{
K. M. Nelwade*, Syed Ismail and R. A. Jadhav \\ Department of Soil Science and Agricultural Chemistry, \\ Vasantrao Naik Marathwada Krishi Vidyapeeth, Parbhani, Maharashtra 431402, India \\ *Corresponding author
}

\begin{tabular}{|l|}
\hline K e y w o r d s \\
Co-inoculation, \\
Biological \\
Properties, Soil \\
Health, \\
Biofertilizers, \\
Microbial count, \\
Enzymatic activity \\
\hline Article Info \\
\hline $\begin{array}{l}\text { Accepted: } \\
\text { 07 September } 2019 \\
\text { Available Online: } \\
\text { 10 October } 2019\end{array}$ \\
\hline
\end{tabular}

A B S T R A C T
The present experiment was conducted to study the changes occurred in biological property under the influence of co-inoculation of different bacterial cultures with Rhizobium phaseoli in blackgram grown Vertisols at Research farm, Department of Soil Science and Agricultural Chemistry, Vasantrao Naik Marathwada Krishi Vidyapeeth, Parbhani. The pre-evaluated bacterial cultures i.e. Rhizobium phaseoli and seven other (Bacillus megaterium, Bacillus subtilis, Bacillus polymyxa, Pseudomonas striata, Pseudomonas flurescens, Azotobacter chroococcum and Azospirilllum lipoferum) in laboratory were used with RDF in randomized block design. Seed treatment of black gram was done with $50 \mathrm{ml}$ of Rhizobium phaseoli and $50 \mathrm{ml}$ of other bacterial cultures along with application RDF at the time of sowing. Results emerged out indicated that the soil microbial population i.e. fungi, bacteria and actinomycetes and enzymatic activity i.e. dehydrogenase, acid phosphotase and alkaline phosphatase were highly influenced by co-inoculation over mono-inoculation and control one. The treatments received co-inoculation of Rhizobium phaseoli with Bacillus megaterium $\left(\mathrm{T}_{4}\right)$, Pseudomonas striata $\left(\mathrm{T}_{7}\right)$ and Pseudomonas flurescense $\left(\mathrm{T}_{8}\right)$ found strongly at par with each other and having more potential than the other combinations.

\section{Introduction}

Indiscriminate use of synthetic chemical fertilizers has led to the pollution and contamination of the soil, has polluted water basins, destroyed micro-organisms and friendly insects, making the crop more prone to diseases and reduced soil fertility (Syed Ismail 2015). At this alarming stage to sustain crop production and maintain soil fertility integrated nutrient management is prime and only option. The biofertilizers are one of the major components of integrated nutrient management having potential to work efficiently to reduce such hazards. Microbial inoculants are cost effective, eco-friendly and renewable sources of plant nutrients. Plant beneficial living microbial cultures (bio- 
fertilizers) are supposed to be a safe supplement to chemical fertilizers in order to minimize the ecological disturbance.

The biochemical properties of soil have often been proposed as early and sensitive indicators of soil ecosystem health. Soil enzymes play an essential role in energy transfer environmental quality, organic matter decomposition, nutrient cycling and crop productivity (Mina et al., 2011). A number of microorganisms are considered important for agriculture to promote better enzyme activity and biological health of soil.

\section{Materials and Methods}

Composite soil samples of $0-15 \mathrm{~cm}$ depth were collected from individual plots after harvesting the crop and stored at low temperature in deep freeze for determination of microbial population and enzymatic activity in soil after harvesting.

For the growth of bacteria, fungi and actinomycetes three different media i.e. Nutrient Agar, Rose Bengal and Ken knight medium respectively were used.

The serial dilution technique described by Dhingra and Sinclair (1993) was used for particular group of microbes. Enzymes i.e. dehydrogenase, acid phosphatase and alkaline phosphates which play important role in soil microbial respiration and phosphorous mobilization respectively were analyzed by using standard procedures described by Tabatabai and Bremner (1969).

The results obtained were statistically analyzed and appropriately interpreted as per the methods described by Panse and Sukhatme (1985). Appropriate standard error (S.E.) and critical differences (C.D.) at 5 per cent levels were worked out for interpretation of result.

\section{Results and Discussion}

\section{Effect on Enzymatic activity}

The data noted in Table 1 indicates the enzymatic activity of soil significantly influenced by co-inoculation of bacterial cultures with Rhizobium phaseoli.

\section{Dehydrogenase activity}

The activity of enzyme dehydrogenase (39.47 $\mu \mathrm{g} \mathrm{g}^{-1}$ soil) was significantly higher in treatment $\mathrm{T}_{7}(\mathrm{RDF}+$ Rhizobium phaseoli + Pseudomonas striata) over other treatments and found at par with treatment $\mathrm{T}_{8}(37.83 \mu \mathrm{g}$ $\mathrm{g}^{-1} \quad$ soil) having co-inoculation of Pseudomonas fluorescens with Rhizobium phaseoli. The minimum dehydrogenase activity (29.57 $\mu \mathrm{g} \mathrm{g}^{-1}$ soil) observed in treatment $\mathrm{T}_{1}$ (absolute control). The dehydrogenase participates in electron transport system of oxygen metabolism so it reflects the extent of oxidative activity of soil microorganisms and is good indicator of microbial activity (Nannipieri et al., 2002) and due to high substrate availability the dehydrogenase activity is also high.

\section{Acid and alkaline phosphatise}

The acid and alkaline phosphatase activities in soil recorded high in treatment $\mathrm{T}_{8}$ (51.63 and $67.72 \mu \mathrm{g} \mathrm{g}^{-1}$ soil, respectively) receiving coinoculation of Pseudomonas fluorescens with Rhizobium phaseoli which significantly differed from other treatments.

The second and third higher value of acid (50.84 and 50.44 $\mu \mathrm{g} \mathrm{g}^{-1}$ soil, respectively) and alkaline phosphatase (66.07 and $65.76 \mu \mathrm{g} \mathrm{g}^{-1}$ soil, respectively) was recorded in treatment $\mathrm{T}_{4}$ (RDF + Rhizobium phaseoli + Bacillus megaterium) and $\mathrm{T}_{7}$ ( $\mathrm{RDF}+$ Rhizobium phaseoli + Pseudomonas striata) which found at par with treatment $\mathrm{T}_{8}$. The minimum acid 
(30.25 $\mu \mathrm{g} \mathrm{g}^{-1}$ soil) and alkaline phosphatase (54.42 $\mu \mathrm{g} \mathrm{g}^{-1}$ soil) activities were recorded in treatment $\mathrm{T}_{1}$ (absolute control). Soil phosphatase play a major role in the mineralization processes of organic $\mathrm{P}$ substrates and their activity can be influenced by soil microbial population (Sarapatka, 2003).

However, activities of these enzymes were not persistent, and sometimes found contrasting. The acid phosphatase activity was much lower than alkaline phosphatase activity, irrespective of the treatments, which may be due to the alkaline reaction of soil (Dick, 1994).

Similarly, Kaleeswari (2007) reported that activities of both acid and alkaline phosphatases were significantly improved over control levels in the rhizosphere up on inoculation. This might be due to increased microbial and root activities.

Further, Nihorimbere et al., (2011) reported more microbial activities increased the dehydrogenase activity in rhizosphere due to more availability of food material for its growth. Badawi et al., (2011) also studied and results revealed that, there was maximum value of nitrogenase activity in Bradyrhizobium + Serratia marcescens among different inoculation treatments.

Similarly, Badda et al., (2013) concluded that triple inoculation of A. laevis $+T$. viridae $+P$. Fluorescence showed maximum increment in both acid and alkaline phosphatase activity.

Moreover, Bodkhe et al., (2014) concluded that an application of $75 \%$ RDF and dual inoculation significantly increased soil enzymes activity. Our findings were matched with results of Sable and Ismail (2017) that activity of alkaline phosphatase and acid phosphatase was noted significantly highest in treatment $\mathrm{RDF}+$ Rhizobium + Bacillus megaterium. Similarly, Vidhyashree et al.,
(2017) reported that dehydrogenase and alkaline phosphatase activity in co-inoculated treatment (PSB + Aspergillus awamori) showed significant increase.

\section{Effect on Microbial population}

The data depicted in Table 2 indicates that the soil microbial population shows distinct differences under the influence of coinoculation of bacterial cultures with Rhizobium phaseoli.

\section{Bacterial population}

With respect to culturable microbial communities of the black gram soil the bacterial load was highest in the treatment $\mathrm{T}_{7}$ (39 CFU X $10^{7}$ ) receiving co-inoculation of Pseudomonas striata and Rhizobium phaseoli which found at par with treatment $\mathrm{T}_{4}(35.33$ CFU X $10^{7}$ ) having co-inoculation of Bacillus megaterium with Rhizobium phaseoli.

The lowest bacterial population recorded in treatment $\mathrm{T}_{1}\left(20.67 \mathrm{CFU} \times 10^{7}\right)$ which is absolute control.

Due to co-inoculation of different bacterial cultures with Rhizobium phaseoli population of native and applied bacteria were increased by multiplication (Bodkhe et al., 2014).

\section{Actinomycetes population}

Among treatments the treatment $\mathrm{T}_{7}$ having coinoculation of Pseudomonas striata with Rhizobium phaseoli found significantly superior in case of actinomycetes population (32.67 CFU X $10^{5}$ ) over rest of treatments and found at par with treatment $\mathrm{T}_{4}(32.33 \mathrm{CFU} \mathrm{X}$ $10^{5}$ ) having co-inoculation of Bacillus megaterium with Rhizobium phaseoli and treatment $\mathrm{T}_{8}\left(30.67 \mathrm{CFU} \times 10^{5}\right)$ receiving coinoculation of Pseudomonas flurescens with Rhizobium phaseoli. 
Table.1 Effect of co-inoculation of different bacterial cultures with Rhizobium phaseoli on enzymatic activities in soil after harvest of black gram

\begin{tabular}{|c|c|c|c|c|}
\hline $\begin{array}{l}\text { Sr. } \\
\text { No. }\end{array}$ & Treatments & $\begin{array}{l}\text { Dehydrogenase } \\
\text { ( } \mu \mathrm{g} \mathrm{g}^{-1} \text { soil) }\end{array}$ & $\begin{array}{l}\text { Acid } \\
\text { phosphatase } \\
\left(\mu \mathrm{g} \mathrm{g}^{-1} \text { soil) }\right.\end{array}$ & $\begin{array}{l}\text { Alkaline } \\
\text { phosphatase } \\
\left(\mu \mathrm{g} \mathrm{g} \mathrm{g}^{-1} \text { soil) }\right.\end{array}$ \\
\hline $\mathbf{T}_{1}$ & Absolute control & 29.57 & 30.25 & 54.42 \\
\hline $\mathbf{T}_{2}$ & Only RDF & 30.83 & 39.03 & 55.64 \\
\hline $\mathbf{T}_{3}$ & RDF + Rhizobium phaseoli & 34.07 & 43.56 & 60.22 \\
\hline $\mathbf{T}_{4}$ & $\mathrm{~T}_{3}+$ Bacillus megaterium & 37.43 & 50.84 & 66.07 \\
\hline $\mathbf{T}_{5}$ & $\mathrm{~T}_{3}+$ Bacillus subtilis & 34.73 & 47.02 & 62.04 \\
\hline $\mathbf{T}_{6}$ & $\mathrm{~T}_{3}+$ Bacillus polymyxa & 32.17 & 40.24 & 57.09 \\
\hline $\mathbf{T}_{7}$ & $\mathrm{~T}_{3}+$ Pseudomonas striata & 39.47 & 50.44 & 65.76 \\
\hline $\mathbf{T}_{8}$ & $\mathrm{~T}_{3}+$ Pseudomonas flurescens & 37.83 & 51.63 & 67.72 \\
\hline $\mathbf{T}_{9}$ & $\mathrm{~T}_{3}+$ Azotobacter chroococcum & 36.30 & 44.26 & 59.99 \\
\hline \multirow[t]{4}{*}{$\mathbf{T}_{10}$} & $\mathrm{~T}_{3}+$ Azospirillum lipoferum & 31.43 & 47.25 & 59.76 \\
\hline & S.Em. \pm & 0.59 & 0.69 & 1.50 \\
\hline & C.D. at $5 \%$ & 1.76 & 2.05 & 4.46 \\
\hline & Initial Soil Sample & 28.60 & 29.96 & 52.20 \\
\hline
\end{tabular}

Table.2 Effect of co-inoculation of different bacterial cultures with rhizobium on microbial population in soil after harvest of black gram

\begin{tabular}{|c|c|c|c|c|}
\hline $\begin{array}{l}\text { Sr. } \\
\text { No. }\end{array}$ & Treatments & $\begin{array}{l}\text { Bacteria } \\
\left(\text { CFUX10 }^{7}\right)\end{array}$ & $\begin{array}{l}\text { Actinomycetes } \\
(\text { CFUX10 })\end{array}$ & $\begin{array}{l}\text { Fungi } \\
\left.\text { (CFUX10 }{ }^{4}\right)\end{array}$ \\
\hline$T_{1}$ & Absolute control & 25.67 & 21.00 & 2.17 \\
\hline $\mathbf{T}_{2}$ & Only RDF & 29.67 & 22.33 & 2.33 \\
\hline $\mathbf{T}_{3}$ & RDF + Rhizobium phaseoli & 31.33 & 26.33 & 3.33 \\
\hline $\mathbf{T}_{4}$ & $\mathrm{~T}_{3}+$ Bacillus megaterium & 35.33 & 32.33 & 4.33 \\
\hline $\mathbf{T}_{5}$ & $\mathrm{~T}_{3}+$ Bacillus subtilis & 31.33 & 26.67 & 3.67 \\
\hline$T_{6}$ & $\mathrm{~T}_{3}+$ Bacillus polymyxa & 29.67 & 22.00 & 3.00 \\
\hline $\mathbf{T}_{7}$ & $\mathrm{~T}_{3}+$ Pseudomonas striata & 39.00 & 32.67 & 5.00 \\
\hline $\mathbf{T}_{8}$ & $\mathrm{~T}_{3}+$ Pseudomonas flurescens & 34.67 & 30.67 & 4.67 \\
\hline $\mathbf{T}_{9}$ & $\mathrm{~T}_{3}+$ Azotobacter chroococcum & 30.00 & 27.33 & 3.67 \\
\hline \multirow{4}{*}{$\mathbf{T}_{10}$} & $\mathrm{~T}_{3}+$ Azospirillum lipoferum & 27.00 & 23.33 & 4.00 \\
\hline & S.Em. \pm & 1.25 & 1.93 & 0.30 \\
\hline & C.D. at $5 \%$ & 3.70 & 5.73 & 0.87 \\
\hline & Initial Soil Sample & 23.00 & 19.00 & 2.00 \\
\hline
\end{tabular}




\section{Fungal population}

In case of fungal population the treatment receiving $\mathrm{RDF}+$ Rhizobium phaseoli + Pseudomonas striata $\left(\mathrm{T}_{7}\right)$ recorded highest fungal load $\left(5.00 \quad \mathrm{CFU} \quad \mathrm{X} \quad 10^{4}\right)$ which significantly differed from other treatments at 5 per cent significance level and treatment $\mathrm{T}_{4}$ (4.33 CFU X 10 $0^{4}$ ) and $\mathrm{T}_{8}\left(4.67 \mathrm{CFU} \mathrm{X} \mathrm{10}{ }^{4}\right)$ having co-inoculation of Rhizobium phaseoli with Bacillus megaterium and Pseudomonas flurescens respectively, found at par with treatment $\mathrm{T}_{7}$. The lowest actinomycets $(21.00$ CFU X 10 $\left.{ }^{5}\right)$ and fungal (1.67 CFU X $\left.10^{4}\right)$ population were recorded in treatment $\mathrm{T}_{1}$ (absolute control).

Increase in microbial population may be due to growth promoting substances secreted by crop during growth period. Similar results were obtained by Saini et al., (2015) showing co-inoculation of endophytic bacteria with Rhizobium noted maximum microbial population.

In line with our work, Goutami et al., (2015) found that the maximum bacterial and fungal population was noticed in the FYM inoculated with biofertilizers while the minimum population was recorded in treatment no biofertilizer and FYM. Similarly, Sable and Ismail (2017) conducted results indicated that highest values of actinomycetes and bacterial population were noted in treatment RDF + Rhizobium and Bacillus megaterium whereas, fungal population was highest in the RDF+ Rhizobium + Trichoderma sp. treated soil. Further, Trabelsi and Mhamdi (2013) reported that soil or seed inoculation may lead to changes in the structure and population of indigenous microbial communities. The variation in efficacy of different treatment combinations indicates the specificity of the inoculation response. These results provide a basis for the selection of an appropriate combination of specific Pseudomonas sp. and
Rhizobium $s p$. which could further be utilized for verifying the symbiotic effectiveness and competitive ability of bio-inoculants under field conditions (Mishra et al., 2011).

Significantly highest values of acid phosphatase and alkaline phosphatase were noted in treatment of Pseudomonas flurescens along with Rhizobium phaseoli and RDF after harvest of black gram while, co-inoculation of Pseudomonas striata with Rhizobium phaseoli helped in enhancement of dehydrogenase activity. The significant increase in bacteria, actinomycetes and fungi in soil after harvest of black gram were recorded with coinoculation of Pseudomonas flurescens along with Rhizobium phaseoli and RDF.

\section{References}

Badawi, F.Sh.F., Biomy, A.M.M. and Desoky, A.H. (2011) Peanut plant growth and yield as influenced by co-inoculation with Bradyrhizobium and some rhizomicroorganisms under sandy loam soil conditions. Annals of Agricultural Science 56, 17-25.

Badda, N., Yadav, K., Kadian, N. and Aggarwal, A. (2013) Impact of Arbuscular Mycorrhizal Fungi with Trichoderma viride and Pseudomona fluorescenson growth enhancement of genetically modified Bt-cotton. Journal of Natural Fibers 10, 309-325.

Bodkhe, A.A., Syed Ismail and Syed Javed Jani. (2014) Effect of chemical fertilizers and microbial inoculants on soybean (Glycine max)- safflower (Carthamus tinctorius) cropping pattern. Green Farming 5(3), 341-345.

Darine Trabelsi and Ridha Mhamdi (2013) Microbial inoculants and their impact on soil microbial communities: a review. BioMed Research International http://dx.doi.org/10.1155/2013/863240

Dhingra, O.P. and Sinclair, I.B. (1993) Basic plant pathology methods. CBS publisher, New Delhi, pp: 179-180. 
Dick, R.P. (1994) Soil enzyme activities as indicators of soil quality. In De Wning soil quality for Sustainable Environment (J.W. Doran, D.C. Coleman, D.F. Bezdicek and B.A. Stewart, Eds.), SSSA Special Publication No. 35, ASA and SSSA, Madison, WI, pp. 104-124.

Goutami, N., Rani, P.P., Pathy, R.L. and Babu, P.R. (2015) Soil properties and biological activity as influenced by nutrient management in rice- fallow sorghum. International Journal Agricultural Research, Innovation and Technology 5(1), 10-14.

Kaleeswari, R.K. (2007) Role of phosphatase enzymes in phosphorous nutrition of crops. Agricultural Reviews 28(2), 149153.

Mishra, P.K., Bisht, S.C., Ruwari, P., Joshi, G.K., Singh, G. Bisht, J.K. and Bhatt, J.C. (2011) Bioassociative effect of cold tolerant Pseudomonas spp. and Rhizobium leguminosarum-PR1 on iron acquisition, nutrient uptake and growth of lentil (Lens culinaris). European Journal of Soil Biology 47, 35-43.

Nannipieri, P., Kandeler, E. and Ruggiero, P. (2002) Enzyme activities and microbiological and biochemical processes in soil. In Enzymes in Environment (R.G. Burns and R.P. Dick, Eds.), Marcel Dekker, New York, pp. 133.

Nihorimbere, V., Ongena, $\mathrm{M}$ and Smargiaji, $\mathrm{M}$. (2011) Beneficial effect of rhizosphere microbial community for plant growth and health. Biotechnological, Agronomical and Environmental Science 5 (2), 327-337.

Panse, V. G. and Sukhatme, P. V., (1967)
Statistical Methods for Agricultural Workers, Indian Council of Agricultural Research, New Delhi.

Sable P. and Ismail Syed (2017) Effect of different microbial inoculants on yield, microbial population and chemical properties in soil of groundnut grown on Vertisol. International Journal of Microbiological Research 9(1), 831-833.

Saini, R., Kumar V., Dudeja S.S. and Pathak D.V. (2015) Beneficial effects of inoculation of endophytic bacterial isolates from roots and nodules in chickpea. International Journal Current Microbiology and Applied Sciences 4(10), 207-221.

Sarapatka, B. (2003) Phosphatase activities (ACP, ALP) in agroecosystem soils. Dissertation, Swedish University of Agricultural Sciences.

Syed Ismail (2015) Liquid biofertilizers for sustainable crop production. Chapter in Emerging Innovative Areas in Agricultural Research $1^{\text {st }}$ Edition, Director of Instruction, VNMKV, Parbhani (MS).

Tabatabai, M.A. and Bremner, J.M. (1969) Use of P-nitrophenyl phosphate for assay of soil phosphatase activity. Soil Biology and Biochemisry 1,301-307.

Vidhyashree, C.V., Naga, S.R., Yadav, B.L., Shivran, A.C. and Singh, S.P. (2017) Influence of phosphorus and biofertilizers on soil fertility and enzyme activity of soils grown under mungbean (Vigna radiata L. Wilczek). International Journal of Current Microbiology and Applied Science 6(12), 737-741.

\section{How to cite this article:}

Nelwade, K. M., Syed Ismail and Jadhav, R. A. 2019. Effect of Co-inoculation of different Bacterial Cultures with Rhizobium phaseoli on Soil Biological Properties. Int.J.Curr.Microbiol.App.Sci. 8(10): 604-609. doi: https://doi.org/10.20546/ijcmas.2019.810.068 